\title{
A história oral de mulheres que viveram no seringal
}

The oral history of women who lived in seringal

La historia oral de mujeres que vivieron en el seringal

\author{
Pedro Vasconcelos Corrêa* \\ Fernanda Costa Oliveira ${ }^{* *}$ \\ Iracema Neno Cecílio Tada**
}

\begin{abstract}
Resumo
Este artigo tem como objetivo geral dar voz às mulheres do Distrito de Fortaleza do Abunã, Município de Porto Velho (Rondônia), região da Amazônia ocidental brasileira, que moraram em seringais localizados na ponta do rio Abunã (RO) e reservas fixadas em terras da Bolívia. De maneira específica, investigou-se a vida no seringal e as relações vividas por essas mulheres. Foi utilizada a pesquisa qualitativa com o método da história oral temática (HOT). Foram entrevistadas quatro mulheres, e os resultados descritos em cinco categorias, permitindo compreender que a ida para o seringal ocorreu com o sonho de mudança de vida e que a realidade se mostrou árdua, com relações de trabalho desiguais em relação ao gênero. Aquelas que lá chegaram ainda crianças relataram sua infância e o ingresso na vida adulta. Fatos significativos que compõem a história de vida dessas mulheres e que, ao serem narrados, emergiram com os sentimentos provocados pelas recordações.
\end{abstract}

Palavras-chave: Abunã. Seringal. Mulheres.

\begin{abstract}
This paper has as its main objective to give a voice to women in Fortaleza's Abunã, Rondônia, the Western Brazilian Amazon region, who lived in rubber plantations located in Ponta do Abunã (RO) and reserves established on lands along the Bolivia river. Specifically, we investigated the plantation life and relationships experienced by these women. Qualitative research with the method of thematic oral history (HOT) was used. Interviews were conducted with four women. The results were described in five
\end{abstract}

Texto submetido em 5 de abril 2014 e aprovado para publicação em 26 de setembro de 2014.

Psicólogo e Mestre em Psicologia pelo Programa de Pós-Graduação, Mestrado em Psicologia da Universidade Federal de Rondônia, na linha Psicologia Escolar e Processos Educacionais, Universidade Federal de Rondônia. Endereço: Rua Capitão Esron de Menezes, n.o 1661 - Bairro Areal, CEP: 76804292.E-mail: pedrovasconceloscorrea@hotmail.com.

* Psicóloga clínica, Universidade Federal de Rondônia. Endereço: Rua Raimundo Cantuária, n. ${ }^{\circ} 5240$ - Bairro Agenor de Carvalho, Porto Velho-RO, Brasil. CEP: 76820-246. E-mail: fe.psi.oliveira@hotmail.com.

*** Professora da Universidade Federal de Rondônia, do Programa de Pós-Graduação, Mestrado em Psicologia. Departamento de Psicologia, área de Psicologia Escolar e Processos Educacionais, Universidade Federal de Rondônia. Endereço: Rua Pirapitinga, n. ${ }^{\circ}$ 1937, casa 22 - Bairro Lagoa, Porto Velho-RO, Brasil. CEP: 76812-146. E-mail: iracematada@ig.com.br. 
descriptive categories which allowed us to understand how on going to the rubber plantation occured a change to the dream life expected and that it has proven to be arduous, labor relations unequal by gender. Those who arrived there recounted their child's childhood and entry into adulthood. Significant facts that make up the story of these women's lives and narrated by them emerged with the feelings provoked by the memories.

Keywords: Abunã. Rubber. Women.

\section{Resumen}

Este trabajo tiene como objetivo general dar voz a las mujeres del municipio de Fortaleza del Abunã, Rondônia, región amazónica occidental brasileña, que vivían en las plantaciones de caucho ubicadas en el extremo del rio Abunã $(\mathrm{RO})$ y reservas establecidas en las tierras de Bolivia. En concreto, se investigó la vida en la plantación y las relaciones experimentadas por estas mujeres. Se utilizó la investigación cualitativa con el método de la historia oral temática (HOT). Se realizaron entrevistas con cuatro mujeres. Los resultados, descritos en cinco categorías descriptivas, nos permitieron entender que la ida a la plantación de caucho sucedió juntamente con el sueño de cambio de vida, y como la realidad se mostró ardua, con relaciones de trabajo desiguales en relación al género. Aquellas que llegaron allí siendo todavía niñas, relataron su infancia y la entrada en la edad adulta. Hechos significativos que conforman la historia de vida de estas mujeres, al ser narrados, surgieron conjuntamente con los sentimientos provocados por esos recuerdos.

Palabras clave: Abunã. Caucho. Mujeres.

\section{Introdução}

mulher é uma das personagens que povoaram a Região Amazônica brasileira no decorrer da extração da seringa, período denominado Ciclo Econômico da Borracha. A entrada da mulher no seringal aconteceu por volta de 1912, momento em que ocorreu queda no preço da borracha. A partir do aparecimento dos primeiros seringais, em 1870, a mulher surgiu no contexto amazônico para constituição da família na região, o que segundo Wolff (2001), possibilitou a fixação de residência dos trabalhadores da borracha e a ocupação da floresta, fato inexistente no Primeiro Ciclo da Borracha, no período de 1870 a 1890, quando ocorreu a primeira migração nordestina para os seringais. A autora descreve que as seringueiras eram descendentes de índios e nordestinos, e que, no início da exploração do seringal, a presença da mulher era um privilégio dos altos funcionários. 
Secreto (2011) destaca que milhares de brasileiros foram recrutados para trabalharem na exploração da seringa durante o governo de Getúlio Vargas. Naquele período, uma verdadeira campanha foi realizada para que as pessoas fossem para o seringal no decorrer de 1930 e 1940, com a ideia veiculada pelas mídias governamentais de uma Amazônia como uma terra de fartura e de enriquecimento econômico (Ferreira, 2011; Magalhães, 2006).

O incentivo fornecido aos trabalhadores que migrassem para a Amazônia e que trabalhassem com a extração da borracha surgiu também em função da Segunda Guerra Mundial. Aquela política se caracterizou por ser um empreendimento resultante do acordo estabelecido entre o Brasil e os Estados Unidos da América (EUA), o que possibilitou a reativação dos seringais e a transformação dos seringueiros em "soldados da borracha" (Lima, 2010; Santos Junior, 2005; Souza, 2011).

Araújo (2004) destaca que, nos seringais do Alto Juruá (Acre), a migração ocorreu de maneira intensa, e milhares de nordestinos foram para aquela região. Estes trabalhavam no seringal e viviam a relação caracterizada como sistema de aviamentos ou "barracão", na qual os seringueiros trabalhavam tão somente para pagar a sua dívida com o "barracão", sem a perspectiva de lucro. Nesse cenário, o trabalhador dependia integralmente do patrão, conhecido como "coronel de barracão" e que fornecia os produtos necessários para a sua permanência no seringal (Albuquerque, 2001; Ribeiro, 2012).

Relativo às relações de trabalho vivenciadas no seringal, Maciel (2011), Nascimento (1998), Pantoja (2006) e Wolff (2011) são categóricos ao afirmarem que a diferença existente na relação de trabalho entre homens e mulheres consistia no não reconhecimento da produção das mulheres e também no fato de elas não serem admitidas como trabalhadoras em muitos barracões, ficando sob a tutela de seus maridos, embora trabalhassem de maneira similar aos homens no corte da seringa.

Ao abordarmos o seringal e as mulheres seringueiras, pretendemos compreender a história como ela foi vivida, considerando também a participação feminina nesse cenário tido como majoritariamente masculino pelo destaque dado por nossa sociedade aos soldados da borracha, analisando, assim, a inserção da mulher no seringal (Cardoso, 2010; Wolff, 2011).

Por meio de narrativas, é possível entender aspectos do cotidiano dessas mulheres que viveram no seringal. A memória como postulada por Bosi (1994) surge comunicando a riqueza e a diversidade de momentos vividos e possibilita humanizar a realidade de quem escuta. 
Em pesquisa sobre as mulheres no seringal, Wolff (2011) apresenta narrativas sobre a sua vida cotidiana no Alto Juruá (Acre), como um elemento fundamental para a construção da perspectiva de si própria e do mundo. No relato das participantes, foi possível compreender o imaginário individual e coletivo permeado por uma teia de narrativas repleta de sentimentos singulares.

Em pesquisas de história oral sobre as visões de gênero no uso dos recursos da floresta amazônica, as participantes proporcionaram um olhar singular marcado pela particularidade oferecida em cada experiência (Maciel, 2011; Montysuma \& Cruz, 2008).

Os estudos em história oral são fundamentais para possibilitar o avanço da psicologia direcionada para a compreensão do singular, da experiência e do significado pessoal de eventos sociais. Assim, pretende-se aqui destacar a contribuição do seringal para a vida das mulheres bem como compreender como esse período contribuiu para as relações por elas vividas.

\section{Método}

\section{Local do estudo}

Esta pesquisa foi realizada no Distrito de Fortaleza do Abunã, no Município de Porto Velho-RO, a $19 \mathrm{~km}$ da BR-364, sentido Acre. As origens da vila são remotas, e os relatos orais mais antigos indicam o período da II Guerra Mundial como de maior fluxo migratório na região, movimento econômico decorrente dos anos dourados do Ciclo da Borracha. Passada a fase da borracha, Fortaleza do Abunã entrou em processo de decadência. Hoje a vila se caracteriza por ser um centro turístico frequentado por rondonienses e acreanos.

\section{Participantes}

Participaram desta pesquisa quatro mulheres selecionadas aleatoriamente, formando uma rede relacional (Meihy, 1996). Cada participante assinou o termo de consentimento livre e esclarecido. As participantes foram nomeadas com personagens do folclore da Região Amazônica, para evitar a sua identificação.

Iara, 87 anos, analfabeta, viúva há 10 anos. Migrou do Ceará para o seringal aos 23 anos, casada com dois filhos e a promessa de uma vida melhor. Após chegar, teve mais sete filhos. Residiu em três seringais, onde produzia os alimentos que consumia e comprava no barracão.

Boitatá, 87 anos, analfabeta, nasceu em um seringal localizado na Bolívia. Não conheceu a mãe, e o pai foi assassinado por índios. Viveu no seringal com 
amigas da família durante a infância e, posteriormente, ficou sozinha. Relata que migrou de seringal a seringal. Teve vários relacionamentos afetivos que geraram cinco filhos. Trabalhou desde menina. Estudou na educação de jovens e adultos (EJA), onde aprendeu a ler e a escrever.

Caipora, 60 anos, veio do Ceará para o seringal Colônia (Bolívia), aos 8 anos, com toda a família. No seringal, seu dia a dia era andar pela floresta, pescar, cortar seringa, colher castanha. Em razão de não existir escolas ali, não estudou.

Cunhã-Poranga, 70 anos, nasceu e foi criada no seringal Montiné (Bolívia), onde constituiu família, teve 16 filhos de partos normais com a ajuda do esposo. No seringal, enterrou quatro filhos por falta de recursos para salvá-los. Fazia de tudo, cortava seringa, trabalhava na roça e criava animais.

Procedimentos, instrumentos para a análise dos dados

A busca pelo significado pessoal decorrente de eventos sociais, a compreensão e a descrição do processo são características fundamentais da pesquisa qualitativa (Minayo, 2008; Bogdan \& Biklen, 1994).

Segundo Meihy (1996), utilizar a história oral como método possibilita a criação de registros de experiências que são fundamentais para compreender uma história de vida. A história oral questiona a própria História e amplia a perspectiva histórica para além dos documentos oficiais. Situa o passado como uma continuidade no presente, e essa condição possibilita a interface entre a linguagem e a memória no momento da narrativa. Delgado (2010) enfatiza que a história oral articula a memória, o tempo e a própria identidade em uma relação direta com o tempo histórico. Para a autora, existe uma contínua comunicação entre a memória privada, biográfica, com a coletividade: nacional e internacional. Acrescentamos aqui a história regional, que, juntamente com as outras duas dimensões, possibilita a criação de uma visão de mundo.

A história oral temática (Meihy, 1996) possibilita um recorte sobre eventos específicos situados no tempo e no espaço. Nesse procedimento, existe um tema central: a vida de mulheres no seringal, possibilitando a reconstrução do fenômeno.

Como procedimento para a coleta dos dados, utilizamos a entrevista gravada em áudio. Para a análise, criamos as seguintes categorias descritivas, considerando os objetivos de nossa pesquisa conforme postulado por Delgado (2010):

a) chegada ao seringal;

b) lembranças do cotidiano no seringal; 

c) os relacionamentos afetivos;
d) as relações de trabalho; e
e) o declínio do seringal. Para análise das narrativas, foram seguidas as fases de transcrição, textualização e transcriação descritas por Meihy (1996).

\section{Resultados e discussão}

A seguir, serão apresentados os resultados e a discussão de acordo com as categorias definidas.

A chegada ao seringal

A concepção da Amazônia como uma terra que promovia a fartura encantou e seduziu algumas pessoas que para lá se dirigiram, inclusive Iara, como nos relatou. No entanto, ao chegar à terra prometida, vinha a surpresa:

Eu vim porque ouvi falar que tinha um dia que o pessoal tava embarcando o pessoal pra Amazônia [...]. Quando nós vinhemos do Ceará, nós fomos pra Extrema [RO], ainda era seringal [...]. Custava o batelão vim com as coisas que a gente precisava tanta crise, meu filho, necessidade [...]. Aí eu digo: ai meu Deus do céu, aonde eu vim desbarrar?!

Iara se caracteriza como a mulher seringueira descrita por Wolff (2001) como sendo a índia e a nordestina. Em sua narrativa da possibilidade de fartura, a perplexidade foi a maneira como reagiu ao deparar-se com a Amazônia, uma terra bem diferente daquela apresentada nas propagandas do governo sobre a "terra prometida". Secreto (2011) enfatiza que ocorreu uma intensa propaganda governamental para arregimentar pessoas para o seringal, estas, por sua vez, descreviam a Amazônia como uma terra com fartura e riqueza, em muitos casos, a mídia visual veiculada apresentava elementos como água e comida à disposição do migrante, realidade que, em muitos casos, diferenciava-se daquela vivida por eles no Nordeste brasileiro, atuando, portanto, como um forte atrativo para a ida para a Amazônia.

De maneira diferente, para Boitatá e Cunhã-Poranga, estar naquele lugar foi uma condição que não dependeu das suas escolhas. Nascer e viver os valores cotidianos do seringal indicou uma visão diferenciada de o porquê estarem ali: 
Eu nasci no seringal mesmo [...], no seringal de Pacoara, na Bolívia [...]. Eu nasci lá pra dentro mesmo [...], o nome de lá do seringal era Condomínio. Eu vivi lá quando ainda era menina e não lembro quando nós vinhemos para cá (referindo-se à Fortaleza do Abunã). (Boitatá).

Ixi, eu nasci lá, me criei lá. [...] Seringal do lado de Boa Vista. É na Bolívia. Eu nasci pra lá. Eu me criei lá, meu pai me criou, meu pai era do tempo do soldado da borracha. Só que ele morreu à míngua sem nunca ver esse dinheiro (Cunhã-Poranga).

Nascer e crescer no seringal indica que o ciclo da borracha não possibilitou uma melhora na qualidade de vida das famílias, como era veiculado nas campanhas governamentais (Lima \& Longo, 2010; Secreto, 2011), pois, como destaca Cunhã-Poranga, seu pai morreu sem dinheiro. Ser considerado um soldado da borracha não contribuiu para uma melhor condição de vida, apesar de ajudar na reativação dos seringais e na transformação dos seringueiros para o status de soldados da borracha, como discutido por Santos Junior (2005), Lima (2011) e Souza (2011).

Caipora veio ainda criança, acompanhando a família, e relatou: "Eu vim com 8 anos do Ceará, interei 9 ano em Porto Velho [RO], 58 [referindo-se ao ano de 1958]. Foi, aí, papai foi pro seringal [...] aí nós moramos lá até ficar grande”.

A chegada ao seringal descrita pelas mulheres possibilita compreendermos que a condição da mulher nos quatro relatos esteve ligada à condição de dependência do marido ou da família, geralmente vinculada ao discurso governamental enganoso, passando a viverem aquela realidade e as influências daquele meio social em sua vida.

\section{Lembranças do cotidiano no seringal}

As lembranças fornecem diferentes elementos para a análise da vida no seringal. Questionada sobre as lembranças que tinha do seringal, Iara relatou:

Tem assim de que eu saí assim pra trabalhar, aí chegava e tem aquelas planta, [...] noite de silêncio, não tinha briga [...] lá no siringal, lá era tranquilo, se tinha festa no barracão não tinha briga, cada um matava um gado, um boi e tinha aquela festa, aí a gente, todo mundo que mora nas colocação, nós ia, aí quando terminava cada qual pro seu canto, nunca teve violência, era bom por isso, e aqui não [referindo-se a vida em Fortaleza do Abunã].

O barracão surge no relato de Iara como um ponto de encontro social no seringal, o que difere da análise de Araújo (2004), que enfatiza o barracão como 
meio de aviamento, onde as pessoas adquiriam os produtos que precisavam para a sua sobrevivência e pagavam com a sua produção, sendo a única ligação dos moradores do seringal com a cidade.

Sobre os perigos da floresta, Iara ressaltou:

[...] Perguntaram se eu tinha coragem de ir só [referindo-se a andar nas estradas do seringal sozinha], eu digo vim [...] fazia viagem pra qualquer canto, pegava o terçado ia embora duma colocação pra outra, eu ia [...] nunca aconteceu nada, parece que era Deus mesmo que me valia, mas o pessoal dizia: você há de esquecer que a onça andou ainda agorinha ali! Eu digo: ela não tá mais lá não. E ia embora.

Ao relatar os perigos da floresta, Iara narrou situações em que, motivada pela necessidade de cortar a seringa, seguia para o trabalho sabendo do risco que corria. O medo dos animais selvagens exigia constante vigilância das famílias. Para Boitatá e Caipora, além dos animais selvagens, os índios também representavam perigo. Estes degolaram o pai de Boitatá e, na narrativa de Caipora, há a lembrança dos roubos:

Quando eu era menina, pescava no rio, [...] só que eu tinha muito medo de índio, né? Tinha índio lá. [...] ficava gemendo assim perto da gente, a gente sentia que era eles né? A gente tava lavando roupa assim no rio, aí eles ficava gritando do outro lado, a gente sabia que era eles, aí corria pra casa, eles só vivia perseguindo a gente assim. Eles já roubaram as nossas coisas, ficamos só com a roupa do corpo.

Diante dessa situação, podemos analisar que, nas propagandas vinculadas pelo governo para a ocupação da Amazônia e exploração da borracha, não havia informação sobre a existência dos índios na regiāo. É preciso entender que talvez os índios se comportassem desse modo, matando ou roubando, porque as suas terras foram invadidas, indicando a falta de ações governamentais para o enfrentamento dessa situação.

Sobre a diversão no seringal, a inocência estava presente nas brincadeiras:

Só mesmo andar no mato mesmo, [...] num tinha diversão de nada [...], nós fazia piseiro, brincava muito, nós brincava de carnaval, a nossa brincadeira era assim, fazia carnaval no tempo do carnaval saía na rádio né, aí nós fazia carnaval lá também. [...] Vixi, quando a mamãe saía de casa nós se vestia assim, vestia a roupa da mamãe escondido da mamãe, aí, quando ela chegava, era peia, nós apanhava que só (Caipora). 
Ela se divertia vestindo as roupas de sua mãe e imitando-a. As brincadeiras ocorriam com eventos do seu cotidiano como qualquer criança nessa fase de desenvolvimento. É interessante notar a presença do rádio como meio de comunicação no seringal.

A realidade de Cunhã-Poranga foi de trabalho com o pai desde quando era criança:

Todo tempo trabalhando desde criança, comecei a trabalhar com 10 anos mais meu pai. Meu pai era doente, eu ajudava ele. Ajudava ele em roça, minha mãe ajudava ele colher, ajuda ele a carregar saco, ajudava ele a defumar a borracha, tudo isso eu fiz, desde criança, fui criada lá meu filho, na batalha, eu fui criada. Meu pai era seringueiro desde o tempo da Guerra.

Ajudar os pais na roça é uma rotina atual no interior brasileiro, onde faltam escolas e espaços culturais para crianças, denotando as grandes diferenças sociais, culturais e políticas entre zonas urbanas e rurais que necessitam de maior atenção de nossos representantes legais. $\mathrm{O}$ relato das mulheres que trabalhavam no seringal realizando trabalho similar ao dos homens está presente nas pesquisas de Nascimento (1998), Maciel (2011), Pantoja (2006), Santos (2010) e Wolff (2001), ao relatarem o trabalho árduo da mulher no seringal. Complementando essas análises, destacamos a fala de Cunhã-Poranga, ao dizer que o trabalho era uma realidade também das crianças em um contexto no qual não existiam escolas; uma contradição diante da realidade fornecida pelo governo da época para a ocupação de terras tão distantes. Neste ponto, nós nos indagamos: a política governamental motivou diversas pessoas a irem trabalhar no seringal e, apesar da proposta oferecida, não manteve as condições mínimas de subsistência e de trabalho?

Ao versarem sobre o seu cotidiano, as mulheres demonstraram uma vida voltada para a realização de atividades da vida diária e de trabalho familiar. Observa-se que a floresta apresentava perigos, como os índios e os animais selvagens, e diariamente os seringueiros se aventuravam nessa realidade. Podese então questionar o estereótipo atribuído ao seringueiro como alguém rude e grosseiro (Lima \& Longo, 2010), acrescentando a eles a coragem, a luta e o trabalho como características intrínsecas à sua presença na floresta. E, assim, pensar a ideia de rude e grosseiro como uma condição exigida e eliciada pelo próprio meio no qual estavam inseridos. 


\title{
Os relacionamentos afetivos
}

$\mathrm{Na}$ esfera dos relacionamentos afetivos, Boitatá narra a rigidez existente na época no comportamento dos pais em relação aos namoros das filhas:

\begin{abstract}
De primeira, o namoro era muito difícil. Menino [...], quando chegava perto de uma noiva, já era para casar com ela, se conhecia muito tempo, mas não chegava perto dela [...], o namoro era diferente. Você namorava um aqui outro pracolá e sentava outro pra cá. Era difícil. Hoje em dia, não, namorar é muito bom... Se agarra logo; hoje em dia, é fogo!
\end{abstract}

Boitatá teve vários parceiros e com eles filhos:

Éramos tudo pequeno, nós morávamos seis irmãos. Aí foi o tempo que eu arrumei companheiro depois, deixei e fiquei pr'aqui e pr'acolá, andando pra cima e pra baixo. Aí arrumei outro companheiro, foi o que eu tive, foi quatro filhos com ele, aí fiquei só trabalhando [...]. Depois ele pegou os meninos e levou, aí eu fiquei sozinha de novo. Arrumei uma menina. Aí fui trabalhá para criar essa menina. Ela tava com um ano; eu tava trabalhando para criar ela, e me juntei com outro que é o pai. [...] Agora sofri demais para criar, olha, eu criei cinco filhos.

O relato de Boitatá revela-nos que o namoro e o casamento eram eventos que ocorriam de maneira rápida, talvez em decorrência do fato de constituir uma família indicar fixação em um local (Wolff, 2011). Boitatá nos mostra que ser casada era fixar-se em um local e dedicar-se ao trabalho; os filhos eram uma consequência. Essa realidade também é notada no discurso de Cunhã-Poranga. Seu relato demonstra também que criar filhos e garantir a sua sobrevivência na primeira infância exigia muito trabalho:

Aí eu me casei lá e continuei na seringa, continuei na seringa, só na seringa, não tinha outro trabalho, só na seringa, eu e ele [referindo-se ao marido]. Aí criei, vei meus filhos, um monte de filho tudo lá, criei... Tive meus filhos tudinho. [...] Caía na cama, puf, pronto [referindose ao nascimento do filho] já começava, pegava ele ajeitava, cuidava num dava banho né, pegava ele, enxugava, deitava, cuidava dele, só ia dar banho mais tarde ou no outro dia de manhã se ele nascesse de noite, aí que dava um banho [...].

\section{As relações de trabalho}

As relações de trabalho foram estabelecias de maneira desfavorável para as mulheres seringueiras que trabalhavam muito, com pouco retorno financeiro: 
Cortar seringa, também era um padecer... custava o batelão vim com as coisas que a gente precisava, tanta crise, meu filho, necessidade, que eles custavam a levar mercadoria. Aí eu ia cortar, tirava aqueles caixinhos de açaí, fazia aquele vinho pra eles tomarem pra voltar a cortar fazer aqueles toletes de borracha. Aí nós, seringa de novo, cortando seringa, aí plantava, botava roça, plantava... Aí tinha feijāo, tinha [...] nós comia, pouco nós comprava do barracão. (Iara)

Trabalhar na roça, na roça assim, armar, fazer, tirar farinha, arroz, tinha a farinha, o arroz que a gente plantava (milho, banana, pra gente se manter sabe). Porque se nós fosse comprar só do barracão, não tinha, não tinha proveito, aí nunca pagava a conta. As coisa eram caro, aí a gente se mantinha assim, só da seringa e do caçar, pescar, nossa vida era assim [...] a gente criava bicho, galinha, pato. [...] plantei em casa, porque lá era, é o recurso pra gente comer, roça a gente tinha muito, fazia farinha, fiz muita farinha. (Cunhã-Poranga)

Observa-se que as participantes cultivavam os alimentos que consumiam, evitando comprar no barracão para não ficarem com dívidas. As relações com o barracão demonstravam o quanto era desigual o retorno financeiro do seringal, sempre pesando contra as próprias mulheres seringueiras (Ferreira, 2011; Souza, 2011). Albuquerque (2001) destaca que o barracão exercia extremo controle sobre as relações de trabalho que se caracterizavam pela troca. Os seringueiros pegavam no barracão utensílios que precisavam e forneciam a mercadoria para pagar. Quando a mercadoria não era suficiente para pagar a conta, aumentava a dívida, estabelecendo-se, assim, uma condição sempre desfavorável para o seringueiro. As condições de trabalho do soldado da borracha eram similares às do trabalho escravo (Pinto, Collins \& Veiga Júnior, 2009; Ribeiro, 2012), com o trabalho no corte da seringa e a manutenção da produção particular de subsistência ocupando o dia de quem trabalhava no seringal. No discurso dessas mulheres, observou-se uma espécie de servidão na relação de trabalho, e quando elas deviam ao barracão, a sua situação piorava:

Menino, a vida de seringal é ruim porque, se você dever alguma coisa esse mês e, no final do mês, você não tiver o produto para cobrir aquela conta, você não vai ter mercadoria para você não; o gerente, vixe... Eu fui uma que sofri demais porque, às vezes, não dava pra gente fazer os produtos para cobrir aquela conta, e a mercadoria não vinha, meus filhos, muitas vezes, chorava de fome. E o seringal te cobria, e o gerente era o [fala o nome do gerente], chegava lá para comprar as coisas, dizia não, não posso vender porque deu a vez e não pagou a sua conta, nós voltava, ia embora [...]. Esses que vieram do seringal, ninguém tem nada porque nós só trabalhava para o patrão mesmo. (Boitatá) 
É interessante ressaltar que o trabalho do corte da seringa e da confecção da borracha foi aprendido na prática cotidiana. Em um relato, notou-se que as pessoas foram levadas a trabalhar no seringal sem o devido preparo ou conhecimento mínimo sobre a floresta amazônica e de como cortar seringa e quebrar a castanha:

Nos chamava de brabo, lá os brabos chegaram! Porque nós vinha do Ceará, [...] chamava nós de brabo, porque nós chegava aqui no siringal, ninguém sabia de nada, eu não via aqueles orisco de castanha (riso), [...] batia no chão chega enterrava, aí o pessoal mangava de mim porque ali só vai cortar quando tiver sadio. Eu batia no chão pra quebrar [referindo-se ao corte da castanha], quebrando castanha jogando no chão que nem teçado num corta, e ela vai quebrando, sei que nós fazia assim mesmo (Iara).

Os que não sabiam cortar castanha, como Iara, tornavam-se motivo de riso, sendo chamados de "brabo" em função de não serem da região. É interessante notar que a participante não se colocou em uma posição passiva, mesmo desconhecendo a técnica, mostrou-se ativa e foi realizar o trabalho com os recursos que tinha e que acreditava poder ajudá-la. Essa postura refletiu todo o dinamismo dessa mulher:

Cortei seringa, colhi daquele extrato quando a gente chegava, aquelas tigelinhas cheias de leite, eu colhia, [...] ficava toda melada, cara, cabelo era tudo melado de leite. [...] ainda quebrei é porque eu num tenho a nota, eu, as meninas queimaram, mais eu quebrei 113 caixas [referindo-se a castanhas]. Eu tirava um dinherinho, num dava nada, era as coisa cara e barata nos produto que a gente fazia tudo era baratinho, eu quebrei esse tanto de castanha [referindo-se as 113 latas], comprei uma garrafa [garrafa térmica] daquela garrafa de esquentar água, fica quente fica frio, menino quase que vai embora meu dinheirinho das castanhas todo, eu digo, aí não vai dar não [...] lá eu tinha o que fazer, a castanha dava dinheiro, a seringa, tudo dava dinheiro, tudo dava dinheiro, num trabalhava com a seringa quem que era preguiçoso.

Verifica-se que o trabalho no seringal era muito diferente do trabalho anunciado pela propaganda governamental (Lima, 2011; Magalhães, 2006). Para Iara, mesmo quando o trabalho rendia muito dinheiro, como quebrar 113 latas de castanha, o valor pago não era suficiente para a aquisição dos bens desejados. Nota-se também a visão de que, na floresta, existiam muitas possibilidades para o trabalho. 
As diferenças nas especificidades de trabalho entre homens e mulheres não existiam, como narra Cunhã-Poranga:

A gente corta de manhã cedo (referindo-se ao corte da seringueira); deixa dez horas, aí dez e meia vai colher, tira três hora, aí você traz aquele leite, bota na bacia, aí poda, tem um buião em cima, enche de coco, coco ou cavaca, aí você vai difumar aquilo, ponhar, vai, tudo isso eu sei fazer, botar pra difumar, caroço de babaçu num tem? [...] Eu não fazia né, eu ajudava.

No seringal, homens e mulheres trabalhavam de acordo com as suas necessidades e força física. Empenharam-se em cortar seringa e retirar da floresta o seu sustento sem distinção para a idade de início do trabalho:

Desde menina que nós trabalhava, nós fomos criados assim no trabalho mesmo, nesse tempo não tinha negócio de estudo; era só trabalho mesmo. Todo mundo que trabalha no seringal, era só trabalhar mesmo [...]. Quando terminava o inverno [época das chuvas], nós ia roçar varadouro, roçar estrada; chegava meio-dia já pra cortar negócio da estrada para cortar seringa, quebrar castanha, tudo isso nós fazia. [...]. Nós fomos criado assim, no trabalho pesado, e ainda tinha um tal de roçado que tinha que plantar e tudo. (Boitatá)

Cunhã-Poranga relatou que seus filhos trabalhavam no seringal desde pequenos e não estudavam, pois não existia escola na área. Os momentos de diversão e de prazer consistiam em sair para pescar e retornar com "baciadas" (referindo-se aos peixes pescados) para alimentar a família.

Entrar no discurso dessas mulheres possibilita compreender as nuances do processo vivenciado no seringal. Verifica-se que a mulher também faz parte do personagem "soldado da borracha", e que é preciso entrar nessas narrativas para desmistificar esse personagem e inserir a mulher nesse processo de construção de identidade na relação com os diferentes elementos que compõem o seringal.

\section{O declínio do seringal}

Com o declínio do seringal, as pessoas que dependiam diretamente dele tiveram de deixar os seus bens e migrarem para a cidade. Nessa transição, perderam sua plantação e animais domésticos, que foram utilizados para pagar a dívida que constituíram no barracão: 
Eu, quando saí do seringal mesmo, nós vinhemos, nós tínhamos muita roça; tivemos o trabalho de desmanchar a roça todinha pra fazer farinha pra pagar a conta pra nós poder vim embora. Porque nós não tínhamos condições de ficar, cobraram o seringal todo, de que quê nós íamos viver? Foi o jeito. [...] eu fico pensando assim, foi um tempo perdido que eu tive no seringal, tempo todinho. (Boitatá, destaque nosso)

A gente [referindo-se ao marido] chamava ele pra sair de lá [risos]. Dizia: homem vamos simbora daqui, porque esses menino tão crescendo, precisa botar na escola, tem que aprender, e a gente, lá todo mundo trabalha melhor, "não, vou cortar seringa" [referindo-se à resposta que o marido dava]. O negócio dele era cortar seringa, aí, hoje em dia, reclama porque num tem jeito, mas ficou sem, só ganhando mau o benefício só. Eu também. Fechou né? [...] Os boliviano invadiro porque era na Bolívia, né. Eles invadiro, revendero tudo. Foi em 85 [refere-se ao ano de 1985]. Foi quando nós viemos pra cá, chegamo aqui, daqui nunca saímo. (Cunhã-Poranga)

Para Boitatá, o fim do seringal foi marcado pela perda dos seus bens em função da necessidade de pagar as próprias dívidas com o barracão, analisando que sua vida no seringal foi um tempo perdido, não esquecendo que lá ela nasceu. Cunhã-Poranga também nasceu no seringal e, em seu relato, mostra que hoje ganha muito pouco com o benefício e que seu desejo de ir embora do seringal não foi atendido pelo marido, e o fim ocorreu quando o seringal foi invadido pelos bolivianos, forçando-os a deixar o local.

Caipora, que fora do Ceará para o seringal, relatou que a decisão de sair do seringal foi desejo dos seus pais e também devido ao ataque dos morcegos, que dificultava a sobrevivência:

Não é porque fechou não, porque papai quis vir mesmo, mamãe num quis mais ficar lá porque nós morava em Colônia; não era em Montiné, não. Quando fechou, foi em Montiné, mas quando fechou em Montiné Colônia, já era, já num tinha mais ninguém não. Deu muito morcego lá, matou as criação tudim, matava boi, matava búfalo, tudo, galinha, até gente se ficasse lá; aí o pessoal saiu tudim. Aqueles morcego que chupava a gente mesmo.

A saída de Iara do seringal foi relatada com tristeza. Narrou que o seringal chegou ao fim, e o dono o vendeu, ficando sem nada em Fortaleza do Abunã: "Acabô, fechô, o dono vendeu [...] com vontade de chorar de deixar minhas coisa. Cê acredita que, aqui, lá eu tinha mais satisfação do que aqui [referindo-se à Fortaleza do Abunã] [...]. Eu num tenho nada aqui”. 
As narrativas demonstraram que as lembranças do seringal surgem resgatando as memórias mais significativas. $\mathrm{O}$ foco da narrativa direcionou-se para $\mathrm{o}$ significativo, aquilo que faz parte da subjetividade e que foi escolhido para ser revelado. E essa característica das lembranças possibilita-nos entender a vida cotidiana das mulheres e as diferentes relações vividas no seringal. As mulheres seringueiras fazem parte da história da Amazônia e são negadas pela história oficial como participantes da ocupação do território amazônico, tendo exercido papel similar ao dos homens, conhecidos como os "soldados da borracha".

\section{Considerações finais}

As lembranças narradas pelas quatro mulheres seringueiras possibilitam-nos compreender a vida no seringal. A pesquisa evidenciou a vida sofrida no seringal por parte da maioria das participantes e o quanto elas e suas famílias foram, de certa forma, enganadas pelo discurso oficial da Era de Ouro da Borracha. Elas se depararam com uma realidade diferente da imaginada, com relações de trabalho beirando à escravidão e sem as mínimas condiçôes instrumentais e técnicas de trabalho, moradia e escola no interior da floresta. Elas estavam "presas" ao seringal.

Com o término da Era da Borracha brasileira, essas mulheres com suas famílias fixaram-se em Fortaleza do Abunã, Distrito de Porto Velho-RO, tendo de recomeçar a vida, sem dinheiro, sem posses, não sendo mais jovens sonhadoras.

Por meio das narrativas e pelo procedimento da história oral, pudemos compreender a experiência vivida por aquelas mulheres em um tempo e espaço particular que contribuíram diretamente para a formação de lembranças e memórias sobre o que foi vivido. No entanto muito há de ser feito. Inúmeros grupos estão em situação de marginalizados pelo Brasil. A realidade das mulheres que viveram no seringal em condiçóes precárias é a história real de inúmeros outros grupos que vivem em um sistema socioeconômico desigual e para os quais a Psicologia precisa intervir para romper com as histórias de sofrimento e de alienação. É preciso ouvir o singular para compreender o processo e as marcas que o social imprime na vida das pessoas. 


\section{Referências}

Albuquerque, G. R. de. (2001, novembro). Natureza, cultura, poder e violência no vale do Juruá - Acre. Proj. História, 23, 285-232. Recuperado a partir de http://revistas.pucsp.br/index.php/revph/article/view/10722

Araújo, M. G. J. de. (2004). Cipó e imaginário entre seringueiros do Alto Juruá. Revista de Estudos da Religiāo, 1, 41-59. Recuperado a partir de http://www.pucsp.br/rever/rv1_2004/t_araujo.htm

Bogdan, R. \& Biklen, S. (1994). Investigação qualitativa em educação. Portugal: Porto.

Bosi, E. (1994). Memória e sociedade: lembranças de velhos. São Paulo: Companhia das Letras.

Cardoso, A. A. I. (2010). Memória e migração: as narrativas de Mário Diogo de Melo sobre o fluxo migratório de cearenses para a Amazônia a partir da segunda metade do século XIX [Resumo]. In Anais, 10 Encontro Nacional de História Oral (Testemunhos: história e política) (pp. 1-12). Recife: Universidade Federal de Pernambuco.

Delgado, L. A. N. (2010). História oral: memória, tempo, identidades. Belo Horizonte: Autêntica.

Ferreira, M. L. F. (2011). A construção do eldorado amazônico no governo Vargas: a representação através da imagem (1940-1945). (Tese de Doutorado não publicada). Universidade Estadual Paulista, Programa de Pós-Graduação em Sociologia, Faculdade de Ciências e Letras, Araraquara.

Lima, F. A. de O. Adelaide Gonçalves, Pedro Eymar Barbosa Costa (orgs.). Mais Borracha para Vitória. Fortaleza: Mauc/Nudoc; Brasília: Ideal Gráfica, 2008, 269 p. Revista de Estudo Amazônico, 1 (1), 159-164.

Lima, V. C. de \& Longo, O. C. (2010, dezembro). A sustentabilidade da habitação do seringueiro amazônico. Pós, 17 (28), 182-197. Recuperado a partir de http://www.revistas.usp.br/posfau/article/view/43707.

Maciel, M. N. (2011, julho, dezembro). O percurso de uma pesquisa: da entrevista a interpretação das narrativas de quatro mulheres que vivenciaram a Amazônia. Revista Educamazônia, 1 (6), 1-19. Recuperado a partir de https:// dialnet.unirioja.es/servlet/articulo?codigo $=4002699$ 
Magalhães, M. das G. S. D. (2006). Amazônia brasileira: processo histórico do extrativismo vegetal na mesorregião do sul de Roraima. (Tese de doutorado). Pontifícia Universidade Católica do Rio Grande do Sul, Programa de PósGraduação em História, Porto Alegre.

Meihy, J. C. S. B. (1996). Manual de história oral. São Paulo: Loyola.

Minayo, M. C. S. (2008). O desafio do conhecimento: pesquisa qualitativa em saúde. São Paulo: Hucitec.

Montysuma, M. \& Cruz, T. A. (2008). Perspectivas de gênero acerca de experiências cotidianas no seringal Cachoeira - Acre (1964-2006). História Unisinos, 3 (12). Recuperado a partir de http://revistas.unisinos.br/index.php/ historia/article/view/5432

Nascimento, M. da G. (1998). O trabalho silencioso da mulher no interior da floresta amazônica. Revista de Educação, Cultura e Meio Ambiente, 11 (2). Recuperado a partir de http://www. revistapresenca.unir.br/artigos_presenca/1 1 mariadasgracasnascimento_ otrabalhosilenciosodamulhernointeriordafloresta.pdf

Pantoja, M. C. (2006). Mulheres nos seringais: etnia, parentesco e afetividade. Somanlu: Revista de Estudos Amazônicos do Programa de Pós-Graduação Sociedade e Cultura na Amazônia da Universidade Federal do Amazonas, 2, 67-92.

Pinto, A. C., Collins, C. \& Veiga Júnior, V. F. da. (2009). Editorial - Amazônia: eldorado ou inferno verde?. Journal of the Brazilian Chemical Society, 20 (6). Recuperado a partir de http://www.scielo.br/scielo.php?script=sci_ arttext\&pid=S0103-50532009000600001\&lng=en\&tlng=pt.

Ribeiro, V. L. (2012, janeiro, junho). Coronel de barranco: entre o pitoresco e a denúncia. Revista de Letras, 1 (1). Recuperado a partir de http://www. nomerevistadeletras.com.br/download/Artigo5.pdf

Santos Junior, P. M. dos (2005, inverno). Pobreza e prostituição na belle époque manauara: 1890-1917. Revista História Regional, 10 (2), 87-108. Recuperado a partir de http://www.revistas2.uepg.br/index.php/rhr/article/view/2217.

Santos, L. (2010, janeiro, março). Milton Hatoum e os seringueiros: o contemporâneo cosmopolitismo amazônico. Revista Iberoamericana, 76 (230), 169-186. Recuperado a partir de http://revista-iberoamericana.pitt.edu/ojs/ index.php/Iberoamericana/article/view/6654 
Secreto, M. V. (2011). Mais borracha para a vitória. Campanha de recrutamento de trabalhadores e fracasso social na exploração de borracha durante o governo Vargas. Estudios Rurales, 1 (1). Recuperado a partir de http://ppct.caicyt.gov. ar/index.php/estudios-rurales/article/download/640/779.

Souza, J. D. (2011). Entre lutas, porongas e letras: a escola vai ao seringal - (re) colocações do Projeto seringueiro (Xapuri/Acre - 1981/1990). (Dissertação de Mestrado). Universidade Federal de Minas Gerais, Programa de Pós-Graduação em Educação, Belo Horizonte.

Wolff, C. S. (2001, novembro). A construção da sustentabilidade nos seringais em crise: uma questão de gênero. Alto Juruá, Acre/Brasil: 1912 a 1943. Proj. História, 23. Recuperado a partir de http://revistas.pucsp.br/index.php/revph/ article/view/10720.

Wolff, C. S. (2011). Mulheres da floresta: outras tantas histórias. Revista Estudos Amazônicos, 1 (6). Recuperado a partir de http://www.ufpa.br/pphist/ estudosamazonicos/arquivos/artigos/1\%20-\%20VI\%20-\%202\%20-\%20 2011\%20-\%20Scheibe_Wolff.pdf 